\title{
A CASE STUDY ON DIMENSIONS OF TOURIST SATISFACTION WITH KAZIRANGA NATIONAL PARK OF ASSAM
}

\author{
Dr. Mriganka Saikia \\ Associate Professor, \\ Department of Economics, \\ Dhing College, \\ Assam, \\ India.
}

Article DOI: https://doi.org/10.36713/epra3941

\begin{abstract}
The purpose of the study is to find out dimensions of tourist satisfaction towards tourism services provided at Kaziranga National Park (KNP) of Assam. All the determinants of dimensions of tourist satisfaction toward the destination will be measured by Five point Likert Scale, ranging from (5) Excellent to (1) Very Poor. The study had collected data with the help of a questionnaire from 450 tourists that have visited KNP during October, 2018-March 2019. The collected data is analyzed using econometric and non-econometric methods to identify the important factors that determine tourist satisfaction. The result indicates factors such as cleanliness, improved amenities and safety and security are very important to ensure overall high level tourist's satisfaction. From findings of the study, it suggests that future of KNP should be a place of important and preferred destination for all domestic and international tourists.
\end{abstract}

KEYWORDS: Tourism, Tourist Satisfaction, KNP and Assam.

\section{INTRODUCTION}

Tourists' satisfaction with a destination as the degree to which a tourist's assessment of the attributes of that destination exceeds his or her expectations for those attributes (Pizam, Neumann and Reichel 1978, Mountiho 1987, Tribe and Snaith, 1998). Tourist's satisfaction is highly heterogeneous. It differs from tourist to tourist and it is a reflection of service quality. Tourist's satisfaction is directly related with the quality of the service. Tourism is one of the top and fastest growing sectors in the world, it plays a very important role in the economy and stimulated the growth of other economy (Osman \& Sentosa, 2013). Tourism is arguably one of the largest self-contained commercial interventions to create happiness on the entire planet (Pearce, 2007). Happiness is directly related to satisfaction, and therefore overall happiness is highly linked to satisfaction in leisure travel sector (Glazter, 2000). The majority of the tourists have experiences with destinations, and their perceptions are influenced by comparisons among facilities, attractions and service standards (Law, 1995). The industry has grown its total contribution to GDP by 3 percent and increased the number of jobs by five million, and therefore one in 11 of all jobs in the world are now supported by Travel and Tourism.

\section{BACKGROUND OF THE STUDY}

Assam, the gateway of the North East India, is the homeland of the two UNESCO recognized heritage sites i.e. Kaziranga National Park and Manas Wildlife Sanctuary. Another tourist destination, Majuli is the world's largest river island and it attracts tourists from all over the world. Assam is a state with many tourist destinations, such as islands, national park, historical monuments and its architectures etc. Its enchanting hills, dancing rivers, thick and dark forests, heavy rain during monsoon, innumerable varieties of flora and fauna, countless species of wild animals and plants, melodious folk music, thrilling dances and festivals, variety of many delicious dishes, handlooms and handicrafts and above all its green landscape used to attract people coming from different parts of the world since time of immemorial. Although Assam is blessed with natural beauty and other tourist destinations, but in terms of contribution to state GDP and employment of Assam is less than that of national average. According to Regional Tourism Satellite Account (2009-10), contribution of tourism to the sate GDP of Assam (2.73 $\%)$ is below the national $(3.8 \%)$ average. The direct share of tourism in Assam to employment (2.87\%) is less in compare to total share of India to total employment $(4.37 \%)$. 
The aim of this study is to measure tourist's satisfaction among international and domestic visitors while embarking for holiday in Kaziranga National Park (KNP), Assam. Kaziranga National Park is one of the important tourist destinations of central Assam. The history of protection of Kaziranga dates back to the early twentieth century, when Baroness Marry Victoria Leiter Curzon, an American who was the wife of Lord Curzon, the then viceroy of India, first visited the Kaziranga area in 1904. Kaziranga had been renowned for its rhinoceros population. After independence in 1950, Kaziranga was declared as wildlife sanctuary and in 1974 it was declared as Kaziranga National Park. Finally in 1985, Kaziranga National Park was declared as world Heritage site by UNESCO. Kaziranga National Park is a name known worldwide for its success in the conservation history of one horned Rhinoceros, provides habitat for a number of threatened species and migratory birds. The Kaziranga National Park is located between longitude $92^{0} 50^{\prime} \mathrm{E}$ and $93^{0} 41^{\prime} \mathrm{E}$ and latitude $26^{0} 30^{\prime} \mathrm{N}$ and $26^{0} 50^{\prime} \mathrm{N}$. Kaziranga's name and fame as one of the best spots for wildlife viewing and its popularity amongst the tourists has been growing since then. Kaziranga occupies a significant position in the international tourist map today as one of the best wildlife resorts in the world. As time passages, KNP is an attraction for tourists, researchers, naturalist, and wildlife enthusiasts in all over the world. The park has been visited by the kings, princes, prime ministers, presidents, Ambassadors, High commissioners, Governors and Ministers from across the world.

\section{REVIEW OF LITERATURE}

Keeping in view the objectives of the study, sufficient literature in line with the present study was reviewed at the international, national and regional levels.

Johnson (1995) has suggested in his paper that policies are needed to improve infrastructure, to promote the integration of tourist services, to maintain visitor numbers, to encourage guests to stay longer, to promote visits to additional locations and to increase their spending.

Bhatia (1991) in his book has viewed that like any other industry, the tourist industry is also subject to like planning, marketing and promotion to attract tourist to the destination.

Sinha (2002) in his book focuses on various crucial issues regarding modern international tourism. It analyses problems relating to transportation of tourists.

Flipe (2006) has made a study on Tourism in Goa in the context of Globalization. The study explains why Goa is able to attract more than $10 \%$ of international tourists in the country.

Chauhan and Khanna (2009) have made a study on terrorism and tourism in Jammu and Kashmir of India. Tourism in India is growing at a comparatively rapid pace. But due to terrorism the pace of growth of tourism in Jammu and Kashmir is getting stagnated.

George (2003) in his research study under the title Management of Tourism Industry in Kerala has made a questionnaire survey for primary data collection. From his study it was found that foreign tourists prefer beaches, backwaters and Ayurveda while domestic tourists prefer nature based tourism including beaches and hill stations.

Shelley (1991) in her study has made an attempt to represent a broad profile of the hospitality industry. The study concludes that the present situation of hotel industry is not sufficient to meet the requirements of tourists.

Mathieson and Wall (1982) in their book describe the requirements of the travellers and of the impacts that they have on the economic, physical and social well being of their hosts. They consider tourism as a consumer product and hence an economic activity having social and physical impacts.

Sharma (1991) advises how to improve the hospitality services associated with tourism in his book as for the healthy development of tourism in a country like India.

Bhat and Nabina (2013) in their paper have considered tourist's satisfaction as important aspects because it considerably influences the tourists' choice of a destination, the consumption of products and services and the decision to visit the destination in the future.

Kumran, Kannan and Milton (2013) in their paper have tried to give an overview about the decision making process in visiting tourist destination, how tourists expectations are met out, how they feel about destination and whether they can recommend this destination to their friends and relatives.

Baruah (2011) in her study has considered tourism as a strategic device to combat environment degradation and at the same time natural sites and objects are the sources of attraction for the tourist.

Rahman (2011) in her paper tries to examine the growth of Kaziranga as a tourist destination on the basis of both primary and secondary data, to enquire into the extent of utilization of national park by the tourist, to examine the accommodation and other facilities available in Kaziranga.

Hussain et al. (2012) in their article have analysed about the livelihood linkages of tourism in Kaziranga National Park. Apart from wildlife viewing, the study has suggested promotion of nature trails and package tours etc. to encourage and enhance tourists to the destination.

An overview of the limited studies on KNP revealed that the majority of the research studies were related to the demographic profile of tourists, factors determining tourist's satisfaction toward KNP and no effort found to be made to study the systematic and econometric study to find out determinants of tourist satisfaction. 


\section{OBJECTIVES}

Tourism is a highly prospering industry with growing socio-economic importance. This study aims at

1. To find out important factors that determines tourist satisfaction.

2. To recommend possible suggestions to provide better services to attract tourist to the destination.

3.

\section{RESEARCH METHODS AND MATERIALS}

To achieve the research objectives, the present study had collected data from tourists visited KNP of Assam. The study is based on the primary data collected from 450 tourists through a questionnaire survey during Oct, 2018-Mar, 2019. Out of 450 tourists, 200 tourists were international and 250 tourists were domestic tourist. All the determinants of dimensions of tourist satisfaction toward the destination will be measured by Five point Likert Scale, ranging from (5) Excellent to (1) Very Poor. The collected data were analyzed using SPSS application. The study has used both descriptive and econometric analysis to evaluate tourist satisfaction on their selected destination.

\begin{tabular}{|c|c|}
\hline \multicolumn{2}{|c|}{ Table 1:Percentage distribution of tourists (N=450) visited the destination } \\
\hline Male & Sex wise Percentage Distribution of Tourists \\
\hline Female & 49 \\
\hline Percentage Distribution of Sample Tourists on the Basis of Purpose of Visit & 65 \\
\hline Holidaying & 25 \\
\hline Visit to Friends and Relatives & 10 \\
\hline Business and Professionals & 45 \\
\hline Percentage Distribution of Sample Tourists on the Basis of Number of Visit \\
\hline First Time & 30 \\
\hline Second Time & 15 \\
\hline Third Time & 10 \\
\hline More than Third Time & 35 \\
\hline Percentage Distribution of Sample Tourists on the Basis of Interest to Visit Again \\
\hline Yes & 45 \\
\hline No & 20 \\
\hline Don't Know & 36 \\
\hline Percentage Distribution of Sample Tourists on the basis of Mode of Local Transport Used \\
\hline Own Vehicle & 6 \\
\hline Government Bus & 12 \\
\hline Official Car & 46 \\
\hline Car Rental & 36 \\
\hline Source: Computed on the basis of primary data collected during the field survey \\
\hline
\end{tabular}

\section{RESULTS AND DISCUSSION}

The findings (as shown in table 1) showed that most of the respondents were male 59 percent and 49 percent were female. The numbers of visits made by tourists for the last tourist season to KNP were 45 percent for first time, 30 percent for second time, 15 percent for third time and 10 percent visited for more than third time.

The purposes of their visit to the KNP were of business and professional (10 percent), holidaying (80 percent), visit to friends and relatives (7 percent only). In response to future visit to the KNP, 35 percent tourists have shown their interest to visit again and 45 percent not interested to revisit the KNP in coming days. The tourists who don't know whether they revisit the KNP is 20 percent. So, large number of tourist not interested to the destination again in near future.

In terms of mode of use of local transport to the destination, most tourists (46 percent) had used rental car, 36 percent used own vehicle, 12 percent used official car and only 6 percent had used government bus to visit the destination. It shows the tourists might not be satisfied with public transport system to visit the KNP.

\section{OVERALL SATISFACTION TOWARD SERVICES PROVIDED IN KNP}

Table-2 presents level of overall satisfactions of the visitors visited the KNP. Findings indicate that 20 percent were highly satisfied and so they rated it as excellent. Hence, 27 per cent rated as good. It shows that less than half of sampled tourists (47 percent) were found to be satisfied with facilities available at KNP. Meanwhile, 42 percent of them have been rated it as moderate only. And 11 per cent tourists were not at all satisfied with the service qualities as they rated poor in their overall satisfaction about the destination. 
EPRA International Journal of Multidisciplinary Research (IJMR) - Peer Reviewed Journal Volume: 6 | Issue: 1 | January 2020 || Journal DOI: 10.36713/epra2013 || SJIF Impact Factor: 5.614||ISI Value: 1.188

\begin{tabular}{|c|c|c|c|c|c|c|}
\hline \multicolumn{6}{|c|}{ Table-2: Percentage distribution of rating of overall satisfactions from services found at KNP } \\
\hline Rating & Excellent & Good & Moderate & Poor & Very Poor & Total \\
\hline $\begin{array}{c}\text { Overall Satisfaction } \\
\text { about Destination }\end{array}$ & 20 & 27 & 42 & 11 & Nil & 100 \\
\hline
\end{tabular}

Source: Computed on the basis of primary data collected during the field survey.

\section{Reliability Test}

The current study has used a popular measure of reliability coefficient alpha i.e. Cronbach's alpha. The reliability study tested to ascertain the stability and consistency of measurement scale. The acceptable level of composite reliability is 0.70 . In this study, the result of Cronbach alpha is found as 0.871 which is very consistence for all the items taken in this study.

\section{Econometric Analysis}

In order to identify important factors that determine the different tourist satisfaction, this study has used multiple regression model. The results of this model presented in table 3. The empirical result shows that about 83 per cent of the variation in the dependent variable (tourist's satisfaction) is due to the explanatory variables and the remaining 17 per cent is due to other unmentioned variables. The adjusted $\mathrm{R}$ squared value was 0.819 . This indicates that 81.9 per cent of the variance in the dependent variable is explained by the variations in the independent variables.

\begin{tabular}{|c|c|c|c|c|c|c|c|c|}
\hline \multicolumn{9}{|c|}{ Table 3: Regression Results - Determinants of Tourist's Satisfaction ( $N=450)$} \\
\hline $\begin{array}{c}\text { Explanatory } \\
\text { Variables }\end{array}$ & $B$ & $S E B$ & t-ratio & $\begin{array}{c}\text { p- } \\
\text { value }\end{array}$ & $B$ & $S E B$ & t-ratio & $\begin{array}{c}\text { p- } \\
\text { value }\end{array}$ \\
\hline Accommodation & .463 & .096 & 4.840 & .000 & .482 & .088 & 5.501 & $.000^{*}$ \\
\hline $\begin{array}{c}\text { Local } \\
\text { transportation }\end{array}$ & .448 & .110 & 4.054 & .000 & .460 & .105 & 4.359 & $.000^{*}$ \\
\hline Landscape beauty & .377 & .110 & 3.424 & .001 & .396 & .092 & 4.304 & $.000^{*}$ \\
\hline Tourist guide & .073 & .082 & .889 & .376 & - & & & \\
\hline Cleanliness & .340 & .092 & 3.680 & .000 & .351 & .087 & 4.033 & $.000^{*}$ \\
\hline $\begin{array}{l}\text { Hospitality of } \\
\text { local people }\end{array}$ & .096 & .057 & 1.678 & .097 & .205 & .054 & 3.796 & $.003^{* *}$ \\
\hline Climate & .325 & .083 & 3.911 & .000 & .335 & .079 & 4.267 & $.000^{*}$ \\
\hline $\begin{array}{c}\text { Safety and } \\
\text { security }\end{array}$ & $5.372 \mathrm{E}-7$ & .000 & .112 & .911 & - & & & \\
\hline Food quality & -.006 & .056 & -.107 & .915 & - & & & \\
\hline Entertainment & -.036 & .055 & -.653 & .516 & - & & & \\
\hline Cost per day & .008 & .056 & .147 & .883 & - & & & \\
\hline \multirow[t]{5}{*}{ Constant } & 2.363 & 0.117 & 20.139 & 0.00 & 2.371 & .091 & 26.174 & $.000^{*}$ \\
\hline & R-square & 0.823 & & & R-square & 0.832 & & \\
\hline & $\begin{array}{c}\text { Adjusted } \\
\mathrm{R}^{2}\end{array}$ & 0.810 & & & $\begin{array}{c}\text { Adjusted } \\
\mathrm{R}^{2}\end{array}$ & 0.819 & & \\
\hline & $\begin{array}{c}\text { F- } \\
\text { statistic }\end{array}$ & 76.992 & $\begin{array}{l}\text { Durbin- } \\
\text { Watson } \\
\text { statistic }\end{array}$ & 1.981 & $\begin{array}{c}\text { F- } \\
\text { statistic }\end{array}$ & 146.844 & $\begin{array}{l}\text { Durbin- } \\
\text { Watson } \\
\text { statistic }\end{array}$ & 1.948 \\
\hline & $\begin{array}{l}\text { P-value } \\
\text { (F) }\end{array}$ & 0.00 & & & $\begin{array}{c}\text { P-value } \\
\text { (F) }\end{array}$ & 0.00 & & \\
\hline & & & & & lected dur & $\begin{array}{l}\text { ely. } \\
\text { g the fie }\end{array}$ & Irvey. & \\
\hline
\end{tabular}

The test of significance (F-test) is accepted at the $1 \%$ and $5 \%$ level of significance. The DurbinWatson (DW) is always between 0 and 4 and the values of $1.5<\mathrm{DW}<2.5$ shows that there is no autocorrelation in the data (Garson, 2012). In this model, the Durbin-Watson statistic is 1.981 . 
Factors such as accommodation, local transport, landscape beauty, tourist guide, cleanliness, hospitality, climatic condition, safety and security and cost per day have positive impact on tourist satisfaction. It is also found that accommodation facilities, local transportation, landscape beauty, cleanliness and climate have significant impact on tourist satisfaction. Table 3 reveals that accommodation has strong impact on tourist satisfaction. Next is local transportation which has a substantial effect on tourist satisfaction. The factors like landscape beauty, cleanliness and climate have also significant effects on tourist satisfaction toward the destination.

\section{IMPLICATIONS OF THE STUDY}

The study provides the strengths and weaknesses of the KNP to the domestic and international tourists. The factors such as cleanliness, improved amenities and safety and security are very important to ensure overall high level tourist's satisfaction. The findings of the study are expected to be expedient in formulating, designing, and implementing policies and programmes for speedy growth and development of tourism sector in Assam. Also findings would benefit the tourism development in particular to the economic growth of the State. The principal guideline of this study is to provide supports for the tourism stakeholders in the process for tourism planning and sustainability of KNP in particular and other destinations in general.

\section{LIMITATIONS OF THE STUDY}

The major limitation of this study is its research area as this study has taken only one destination of Assam, but it could have better if it covered some major destinations of the State. Another major limitation of the study were research scope and boundaries were not wide enough to cover information such from Government Agency, Ministry of Tourism and other organisation associated with tourism of Assam. In addition, more respondents from foreign tourists would be required to provide better picture of evaluation about the destination and available facilities of tourism in the State. Hence, further study can be conducted with the help of more data from tourist visited KNP using exploratory factor analysis and other relevant econometrics to identify more effective factors that stand as obstacle to make KNP as a most sought after destination in the world.

\section{CONCLUSION AND RECOMMENDATIONS}

The international tourists were satisfied with the availability of tourism brochure in English yet they were dissatisfied with the way of speaking this language among local people at the destinations which has been classified as average. Thus, it is important for service providers like hotels, travel agents, ticketing companies and tourist information centers in KNP to recruit the front liner effectively for better hospitality and services for tourists. Some other major dissatisfaction among them is regarding the cleanliness of the public toilet, better amenities and better connectivity toward the destination. Therefore, greater maintenance and services should be done to keep the toilet clean besides ensuring an adequate provision of it at major destinations. Also basic amenities should be improved so as to attract more international tourist to KNP in near future. Meanwhile the majority of the tourists are satisfied with the accessibility to destinations although the overcrowding is always occurring at the destinations. However, this issue should be taken into consideration by the concerned authority as to ensure tourists' satisfaction level is satisfactory. Moreover, less than half of tourists are satisfied with the availability of shopping facilities as most of them like to go for shopping while travelling. Then, it is suggested that the social carrying capacity study to be conducted for better management of the destinations. In addition, most of them were unable to witness the cultural show like traditional music and dance and which make them feel dissatisfied. All tourists want to be entertained while travelling and therefore the tourism authority should take action on it in order to improve their level of satisfaction.

\section{REFERENCES}

1. Pizam, A., Neumann, Y. \& Reichel, A. (1978). Dimensions of tourism satisfaction with a destination area. Annals of Tourism Research, 5(3), 314-322.

2. Moutinho, L. (1987). Consumer behavior in tourism. European Journal of Marketing, 21(10), 1 44.

3. Tribe, J., \& Snaith, T. (1998). From SERVQUAL to HOLSAT: Holiday satisfaction in Varadero, Cuba. Tourism Management, 19, 25-34.

4. Osman, Z. \& Sentosa, I (2013). Mediating effect of customer satisfaction on service quality and customer loyalty relationship in Malaysian rural tourism. International Journal of Economics and Management Studies, 2 (1).25-37.

5. Pearce, P.L., (2007). The relationship between positive psychology and tourist behaviour studies. International Academy for the Study of Tourism Conference, Mugla, Turkey.

6. Laws, E. (1995). Tourist destination management: issues, analysis and policies. New York: Routledge.

7. Glazter, W. (2000). Happiness: classic theory in the light of current research. Journal of Happiness Studies, 1(4), 501-511.

8. Johnson, M. (1995). Czech and Slovak tourismpatterns, problems and prospects. Tourism Management, 16 (1), 21-28.

9. Bhatia, A.K (1991). International tourism. New Delhi: Sterling Publishers Private Ltd.

10. Sinha, P.C. (2002). Tourism, transport and travel management. New Delhi: Anmol Publications Pvt. Ltd.

11. Flipe, R.M. (2006). (Ed.). Globalization of tourism and its impact: A case study of Goa. International 
Tourism Issues and Challenges (pp. 248-256). New Delhi: Kanishka Publishers and Distributors.

12. Chauhan, V., \& Khanna, S. (2009). Tourism: A tool for crafting peace process at Kashmir in India. Tourismos, An International Multi-disciplinary Journal of Tourism.4(2), 50-55.

13. George, P.O. (2003). Management of tourism industry in Kerala. (Doctoral thesis, Mahatma Gandhi University, Kottayam, Kerala).

14. Shelley,L.(1991). Tourism development in India - A study of the hospitality industry. Jaipur: Arihant Publishers.

15. Mathieson, A., \& Wall, G. (1982). Tourism: Economic, physical and social impacts. New York: Longman.

16. Sharma, K.K.(1991). Tourism in India. Jaipur: Classic Publishing House.

17. Bhat,A.M., \& Qadir, N.(2013). Tourist satisfaction in Kashmir: An empirical assessment. Journal of Business Theory and Practice, 1(1), 152-166.

18. Kumaran,S., Kannan,R. \& Milton, T.(2013). Tourist satisfaction with cultural heritage sites at Madurai. Asia pacific journal of marketing and management review. 2 (3), 62-68.

19. Baruah, J. (2011). Impact of tourism on the environment of Assam. In Hemanga, R.C. \& Smaran, S. (Eds.), Tourism in North East India (pp. 148-152). Guwahati: Purbanchal Prakesh.

20. Rahman,Ume,K. (2011). Kaziranga national park as wildlife tourist destination of Assam. In Hemanga, R.C. \& Smaran, S. (Eds.), Tourism in North East India (pp. 148- 152). Guwahati: Purbanchal Prakash.

21. Hussain, S.et.al (2012). An analysis of livelihood linkages of tourism in Kaziranga national park: Natural world heritage site in India. Parks, 18 (2), $32-41$. 